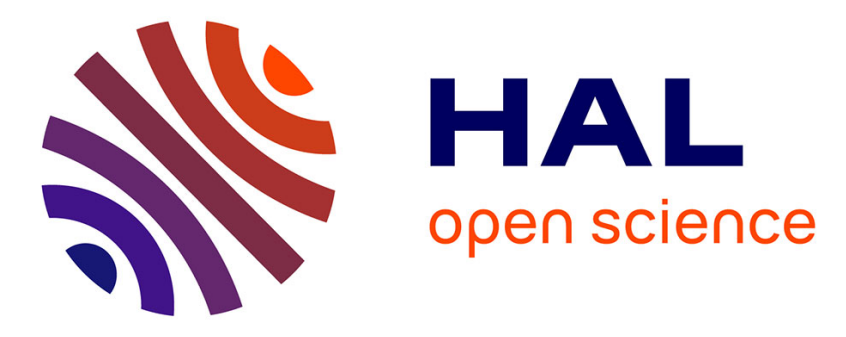

\title{
The use of chromium reduction in the analysis of organic carbon and inorganic sulfur isotope compositions in Archean rocks
}

Élodie Muller, Magali Ader, Carine Chaduteau, Pierre Cartigny, Franck Baton, Pascal Philippot

\section{To cite this version:}

Élodie Muller, Magali Ader, Carine Chaduteau, Pierre Cartigny, Franck Baton, et al.. The use of chromium reduction in the analysis of organic carbon and inorganic sulfur isotope compositions in Archean rocks. Chemical Geology, 2017, 457, pp.68-74. 10.1016/j.chemgeo.2017.03.014 . hal02128682

\section{HAL Id: hal-02128682 \\ https://hal.science/hal-02128682}

Submitted on 14 May 2019

HAL is a multi-disciplinary open access archive for the deposit and dissemination of scientific research documents, whether they are published or not. The documents may come from teaching and research institutions in France or abroad, or from public or private research centers.
L'archive ouverte pluridisciplinaire HAL, est destinée au dépôt et à la diffusion de documents scientifiques de niveau recherche, publiés ou non, émanant des établissements d'enseignement et de recherche français ou étrangers, des laboratoires publics ou privés. 


\section{Accepted Manuscript}

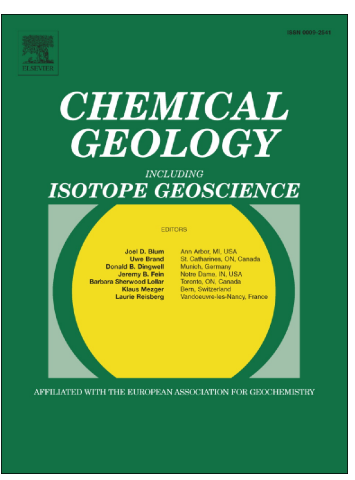

The use of chromium reduction in the analysis of organic carbon and inorganic sulfur isotope compositions in Archean rocks

Élodie Muller, Magali Ader, Carine Chaduteau, Pierre Cartigny, Franck Baton, Pascal Philippot

PII: $\quad$ S0009-2541(17)30139-0

DOI: $\quad$ doi: $10.1016 /$ j.chemgeo.2017.03.014

Reference: $\quad$ CHEMGE 18282

To appear in: $\quad$ Chemical Geology

Received date: 5 December 2016

Revised date: $\quad 7$ March 2017

Accepted date: $\quad 14$ March 2017

Please cite this article as: Élodie Muller, Magali Ader, Carine Chaduteau, Pierre Cartigny, Franck Baton, Pascal Philippot, The use of chromium reduction in the analysis of organic carbon and inorganic sulfur isotope compositions in Archean rocks. The address for the corresponding author was captured as affiliation for all authors. Please check if appropriate. Chemge(2017), doi: 10.1016/j.chemgeo.2017.03.014

This is a PDF file of an unedited manuscript that has been accepted for publication. As a service to our customers we are providing this early version of the manuscript. The manuscript will undergo copyediting, typesetting, and review of the resulting proof before it is published in its final form. Please note that during the production process errors may be discovered which could affect the content, and all legal disclaimers that apply to the journal pertain. 


\title{
The use of chromium reduction in the analysis of organic
}

\section{carbon and inorganic sulfur isotope compositions in Archean}

\author{
rocks.
}

Élodie Muller ${ }^{1 *}$, Magali Ader ${ }^{1}$, Carine Chaduteau ${ }^{1}$, Pierre Cartigny ${ }^{1}$, Franck Baton ${ }^{2}$, Pascal Philippot ${ }^{1}$

${ }^{1}$ Institut de Physique du Globe de Paris, Sorbonne Paris Cité, Université Paris Diderot, UMR 7154 CNRS, F-75005 Paris, France

${ }^{2}$ Metis, Université Pierre et Marie Curie, UMR 7619 CNRS, F-75005 Paris, France

*Corresponding author: Institut de Physique du Globe de Paris, 1 rue Jussieu, 75238 Paris cedex05, France, emuller@ipgp.fr, Tel. +33183957392

\section{ABSTRACT:}

One of the most serious issues with deciphering the evolution of organisms and their biogeochemical environments from the ancient rock record is the difficulty in obtaining well-preserved samples. Although not much can be done to avoid diagenetic and metamorphic alteration when they have occurred, alteration due to weathering can be avoided by working on drill core samples. This implies however that the amount of sample is limited, which may in turn restrain the number of possible chemical and isotopic analyses that can be performed. In order to save sample we show here that the chemical protocol used for the sulfur sulfide extraction (for later sulfur isotope analyses) is also suitable to decarbonate samples (for later organic carbon isotope analyses). In the case of carbonated rocks, both sulfur sulfide extraction and decarbonation require high amounts of sample so that coupling them may save a significant amount of sample and time. In addition it allows both organic carbon (TOC and $\delta^{13} \mathrm{C}$ ) and sulfur isotope 
composition measurements to be performed on the exact same powder, which is essential when trying to understand couplings between $S$ and $C$ cycles in heterogeneous samples. We thus tested the efficiency of the acidic chromium solution, commonly used to extract sulfur from sulfide, for sample decarbonation on various Archean rocks. Our results show that no significant carbon isotope fractionation is caused by this new decarbonation protocol, even for the samples with low organic carbon content. The chromium solution seems to be perfectly adapted for the analysis of organic matter in the ancient rock record, at least when the rock samples have experienced low greenschist facies metamorphism. Further tests will be needed to verify if this protocol can also be used for less mature organic matter.

Keywords: carbon isotopes, decarbonation, limited sample, Precambrian

\section{HIGHLIGHTS:}

- One chemistry for both sulfur sulfide extraction and rock sample decarbonation

- A new protocol that saves time and a significant amount of limited sample

- Organic carbon and sulfur isotope composition analysis on the exact same powder

\section{INTRODUCTION}

As shown by Lowe and Tice (2007), vanishingly few Archean rock units have survived to the present (less than $10 \%$; Garrels and Mackenzie, 1971) and outcrops have been affected by modern oxidative weathering. This surficial weathering can modify both the mineralogy and chemistry of the ancient rock record and thus represents an issue when investigating paleoredox conditions and early traces of life (Hoashi et al., 2009, French et al., 2015). In order to recover relatively well-preserved rock samples from below the present weathering profile 
(below the groundwater table $\sim 10-50 \mathrm{~m}$ ) and to obtain continuous rock cores that retain soft or friable units that outcrop poorly at the surface, several scientific drilling programs have been carried out in Archean terrains in the past decade (Kaufman et al., 2007, Yamaguchi et al., 2009, Philippot et al., 2009). The recovered cores have been extensively analyzed to investigate conditions at the surface of the Archean Earth: the composition, temperature, and redox state of the Archean ocean and atmosphere; the volcanic and sedimentary processes that operated early in Earth history; and above all, to search for pristine morphological or chemical traces of early life (Mojzsis et al., 1996, Philippot et al., 2007, Schopf et al., 2007, Thomazo et al., 2009b, Bontognali et al., 2012).

Since the first description of recognizable Archean microfossils a few decades ago (e.g. Dunlop et al., 1978, Buick et al., 1981), morphology-focused imaging techniques of fossillike objects (Brasier et al., 2002, Schopf et al., 2002, Lepot et al., 2008, Wacey et al., 2011) have failed to absolutely confirm their biogenic origin. This is mainly because several abiologic metamorphic and hydrothermal reactions have been identified that could produce kerogen-like polymers and graphite (e.g. Van Zuilen et al., 2002) and generate complex structures similar to microfossils (e.g. Garcia-Ruiz et al., 2003) and stromatolites (e.g. Grotzinger and Rothman, 1996). In view of these uncertainties and controversies, it is now recognized that studies of early life and associated environmental conditions depend on the multiplication of structural, isotopic and chemical tracers. Particularly, sulfur and carbon isotopes have been traditionally used to decipher ancient biogeochemical cycles (e.g., review in Thomazo et al., 2009, Farquhar et al., 2010). Indeed, C and S isotopes retain records of microbial metabolisms where secondary processes such as metamorphism and weathering have obliterated or erased evidence for early life such as microfossils or other biogenic remains. 
A prerequisite for measuring carbon isotopes of organic material in rocks (and sediments) is to eliminate carbonates which are widely occurring in various forms, i.e. mainly ankerite, dolomite and siderite in Archean rocks, since the isotopic value of the carbon atom of the carbonate would otherwise bias the isotopic signal. In the past, several methods dissolving carbonates by acid-treatment, thereby eliminating the carbonate carbon as carbon dioxide, have been described (Froehlich, 1980, Weliky et al., 1983, Hedges and Stern, 1984), the most commonly used being $10 \% \mathrm{HCl}$ followed by rinsing with deionized water (Schubert and Nielsen, 2000). In parallel, sulfur extraction for isotopic analysis of sulfides and sulfates is generally performed with a succession of different acidic attacks on sample powder. Therefore, sample preparation for either bulk $\mathrm{C}$ or $\mathrm{S}$ isotopic analyses is time consuming and requires important and independent quantities of sample, which are limited when working on drill core samples.

In this study, we tested the chemistry used for sulfur extraction and based on acidic chromium reduction for decarbonation of sample powders in order to save both time and sample and most importantly to perform bulk organic carbon and sulfur isotope measurements in the exact same samples. To our knowledge, this chemistry has never been used for simple decarbonation, and our objective here is thus to test if it is suitable for the determination of the Total Organic Carbone (TOC) content and carbon isotope compositions $\left(\delta^{13} \mathrm{C}_{\mathrm{org}}\right)$. Ader et al. (2009) showed that the even standard decarbonation might lead to an increase by up to $1.4 \%$ in $\delta^{13} \mathrm{C}_{\text {org }}$ values especially for samples with low amount of organic carbon and without changing significantly the TOC contents. Given the hotter (around $190{ }^{\circ} \mathrm{C}$ ) conditions of the acidic chromium chemistry compared to a standard decarbonation procedure, one may be concerned by its effects on the TOC and $\delta^{13} \mathrm{C}_{\text {org }}$ values. In order to investigate such effects we compared the results obtained after the acidic chromium chemistry and the standard 
decarbonation on a selection of Precambrian rock samples with representatively low TOC contents $(<1 \mathrm{wt} \%)$.

\section{SAMPLES}

The samples studied here have been selected among some of the oldest best-preserved Archean rocks in the world. They stem from the Mapepe and Mendon formations on the Kaapvaal Craton (South Africa) and the Tumbiana and Kazput formations on the Pilbara Craton (Western Australia). These units, which have been deposited between 3.24 and 2.32 Ga, present various lithologies representative of the Archean eon. Geological details have been published in previous studies (Philippot et al., 2009, 2012, Thomazo et al., 2009, Martindale et al., 2015), and a short summary of pertinent information is given here. The selected rock samples present low TOC contents between $0.01 \%$ and $0.40 \%$ and a broad range of carbonate concentrations between $0.07 \%$ and $63.80 \%$, which are representative of the Archean rock record.

\subsection{Mapepe and Mendon Formations}

Mendon and Mapepe formations belong to the Barberton Greenstone Belt (South Africa), which consists of a succession of Archean supracrustal rocks surrounded and intruded by granitoids (Viljoen and Viljoen, 1969). The Mendon Formation is mainly composed of ultramafic volcanics, interpreted to reflect large mantle plume magmatic activity (Lowe, 1994), alternated with bedded black cherts, probably recording deep-water sedimentation during times of magmatic quiescence (Hofmann and Harris, 2008). Radiometric age constraints on the tuffaceous band from the underlying Kromberg Formation provide a lower age limit of $3334 \pm 3$ Ma (Byerly et al., 1996). The unconformably overlying Mapepe Formation records shallow-water terrigenous and volcanoclastic sediments, interbedded with 
bedded barite deposits. Zircon ages constrain the Mapepe Formation between $3259 \pm 3$ and 3226 \pm 3 Ma (Kröner et al., 1991, Byerly et al., 1996). Both formations experienced only low greenschist facies regional metamorphism with a maximum temperature of $300{ }^{\circ} \mathrm{C}$ (Knauth and Lowe, 2003, Tice et al., 2004) together with some deformation.

The samples analyzed in the present work were collected from a weathering-free drill core recovered by the Barberton Barite Drilling Project (BBDP; Philippot et al., 2009, 2012) at the so-called "barite syncline" locality. They have been selected as representative of the different lithologies forming the Mendon and Mapepe formations and include one basaltic komatiite and three carbonaceous black cherts from Mendon, together with two bedded barites, two ferruginous cherts, and four silicified terrigenous and volcanoclastic sediments from Mapepe (see Philippot et al., 2012 for more details). Except for black cherts, the other lithologies present low organic carbon content, as deduced from a petrographic observation. Quartz, green chlorite, Fe-Mg-carbonate, barite and pyrite represent the main mineral assemblage.

\subsection{Tumbiana Formation}

The Tumbiana Formation belongs to the Hamersley Basin (Western Australia), which presents a well-preserved succession of volcanic and sedimentary rocks deposited between 2.77 and $2.41 \mathrm{Ga}$ on the granitoid-greenstone basement of the Pilbara Craton (Thorne and Trendall, 2001). This formation consists of large-scale cross-bedded calcareous sandstone, stromatolitic and fenestrate carbonate, and micaceous sandstone interlayered with volcanic siltstone (Thorne and Trendall, 2001, Thomazo et al., 2009). The Tumbiana Formation was deposited at $2724 \pm 5 \mathrm{Ma}$, as indicated by zircon U-Pb dating (Blake et al., 2004), either in a shallow marine or lacustrine environment associated with influx of riverine freshwater derived from the continents (Buick, 1992, Thorne and Trendall, 2001, Bolhar and Van Kranendonk, 2007). The regional metamorphic temperature has been estimated $<300{ }^{\circ} \mathrm{C}$ 
using metamorphic mineral assemblages and the degree of organization of organic matter (Lepot et al., 2008).

The samples have been collected in the Pilbara Drilling Project (PDP1) diamond drill core, which recovered the upper section of the Tumbiana Formation at Meentheena. These include: one siltstone, one laminated mudstone and two homogeneous mudstones. In all samples, organic matter is homogeneously disseminated. Quartz, green chlorite, carbonate (mainly calcite) and pyrite represent the main mineral assemblage throughout the drill core. The $\delta^{13} \mathrm{C}_{\text {org }}$ values of the Tumbiana samples studied here were previously determined by Thomazo et al. (2009).

\subsection{Kazput Formation}

The Kazput Formation consists of subtidal stromatolites, grainstones, and micrites deposited on a mixed carbonate-siliciclastic shelf and is lying within the upper part of Turee Creek Group in the southern Pilbara region of Western Australia (Martindale et al., 2015). The Turee Creek Group is though to be a continuous stratigraphic sedimentary section hosting both the Great Oxidation Event and possibly two Huronian glaciations (Van Kranendonk et al., 2015, Van Kranendonk and Mazumder, 2015). Geochronological constraints for the Turee Creek Group are provided by the $2449 \pm 3$ Ma Woongarra Rhyolite at the top of the underlying

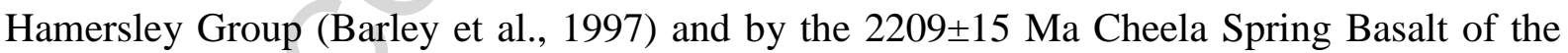
unconformably overlying lower Wyloo Group (Martin et al., 1998).

The samples selected for this study come from the Turee Creek Drilling Project \#3 (TCDP3) drill core and consist of four carbonated mudstones and one quartzite with low organic carbon content (as deduced from a petrographic observation) and mainly composed of quartz, carbonate, chlorite and pyrites. 


\section{METHODS}

Twenty-one rock samples were powdered to $<100 \mu \mathrm{m}$ using a ring and puck mill. For fourteen samples, one single powder has been homogenized, processed using either the standard or the acid chromium method and analyzed for organic carbon content and isotope composition (Table 1). For seven additional samples, different initial powders have been used for the two different decarbonation techniques (Table 2).

\subsection{Standard sample decarbonation}

This method is a common procedure widely used to remove various carbonates such as calcite, andesite, dolomite and siderite (e.g. Bernasconi et al., 1997, Wu et al., 1999, Lorrain et al., 2003, Thomazo et al., 2009). Sample powders (about $200 \mathrm{mg}$ ) were reacted with excess $\mathrm{HCl}(6 \mathrm{~N})$ at room temperature in glass beakers during one night. After removing the supernatant, samples were acidified again with $\mathrm{HCl}(6 \mathrm{~N})$ at $80^{\circ} \mathrm{C}$ and agitated during two hours: this is to guarantee full sample decarbonation. After decantation, the residues were rinsed with deionized distilled water until neutral, centrifuged, and dried at $60{ }^{\circ} \mathrm{C}$ overnight. During this step, acid-volatile sulfur (AVS) such as $\mathrm{FeS}$ or $\mathrm{ZnS}$ would react and release $\mathrm{H}_{2} \mathrm{~S}$, some being potentially re-oxidized into insoluble elemental sulfur (Rice et al., 1993). Pyrite would however remain.

\subsection{Combined sulfur sulfide extraction and sample decarbonation}

The acidic $\mathrm{CrCl}_{2}$ solution is extensively used for the extraction of reduced inorganic sulfur compounds in different types of geological samples, including modern sediments and ancient shales (Canfield et al., 1986, Fossing and Jorgensen, 1989), acid-sulfate soils (Sullivan et al., 2000, Burton et al., 2008), and basaltic glasses (Labidi et al., 2012). It was first designed by Traube and Passarge (1916) for the reduction of (non-sulfur bearing) complex organic 
compounds (e.g. maleic, fumaric or cinnamic acids; Holmquist, 1969). This chemistry was first introduced to the geochemical community by Zhabina and Volkov (1978), and later improved by Canfield et al. (1986) and Gröger et al. (2009) for sulfur extraction. Gröger et al. (2009, p. 21) have shown that $\mathrm{CrCl}_{2}$ solution typically yields $99 \pm 1 \%$ for both pyrite and elemental sulfur. In contrast, simple organic molecules are hardly reduced, with very low yields $<0.2 \%$ (Gröger et al., 2009, p. 24). For more complex organic molecules, polysulfur bonds could be broken by the $\mathrm{CrCl}_{2}$ solution. However, organic sulfur, to be quantitatively reduced, requires the use of Raney-nickel catalyst (e.g. Oduro et al., 2011).

Originally, the $\mathrm{CrCl}_{2}$ solution was prepared and injected using a so-called Jones reductor, which is somewhat complex and time-consuming (i.e. a glass-column packed with granulated $\mathrm{Zn}$ amalgamated for a few minutes with an acidic $2 \%$ mercuric nitrate solution and washed with three column volumes of $0.5 \mathrm{~N} \mathrm{HCl}$; Zhabina and Volkov, 1978, Canfield et al., 1986, Tuttle et al., 1986, Fossing and Jorgensen, 1989). As mostly done worldwide, we prepared our $\mathrm{CrCl}_{2}$ solution daily using a much simpler procedure, where chromic chloride hexahydrate associated with granulated $\mathrm{Zn}$ is acidified with $\mathrm{HCl} 0.6 \mathrm{~N}$ under continuous flow of $\mathrm{N}_{2}$. On reduction, the chromium solution changes from green to blue, reflecting the valence change from chromic (III) to chromous (II) ion.

Sulfur extraction is undertaken adding $20 \mathrm{~mL}$ of freshly prepared $\mathrm{CrCl}_{2}$ solution $(2.1 \mathrm{~N})$ and $10 \mathrm{~mL}$ of concentrated $\mathrm{HCl}(6 \mathrm{~N})$ to $\sim 1 \mathrm{~g}$ of sample powder in the digestion flask at $\sim 100{ }^{\circ} \mathrm{C}$. As long as $\mathrm{N}_{2}$-gas bubbles through the solution, we did not face any sample powder aggregation that would prevent full decarbonation. In these hot, reducing and acidic conditions, reduced sulfur species $\left(\mathrm{S}^{0}\right.$ and $\left.\mathrm{S}^{2-}\right)$ are quantitatively decomposed into $\mathrm{H}_{2} \mathrm{~S}$ (sulfate remains stable). Then, the released $\mathrm{H}_{2} \mathrm{~S}$ is transferred with a stream of $\mathrm{N}_{2}$ from the reaction flask to the sulfide trap filled with $\mathrm{AgNO}_{3}(0.3 \mathrm{M})$ where it reacts to precipitate $\mathrm{Ag}_{2} \mathrm{~S}$ (Trap 2 in Figure 1). A trap filled with distilled $\mathrm{H}_{2} \mathrm{O}$ (Trap 1 in Figure 1) is intercalated in the 
transfer between to reaction flask and the Trap 2 to clean the gas from any acid vapors that have not been stopped by the condenser. Approximately one hour is needed until completion of the $\mathrm{H}_{2} \mathrm{~S}$ transfer, as confirmed by the fact that no additional $\mathrm{Ag}_{2} \mathrm{~S}$ would precipitate if the $\mathrm{AgNO}_{3}$ trap was changed. At the end of the reaction the sample powder residue, which has been decarbonated by the hot acidic $\mathrm{CrCl}_{2}$ solution, is rinsed with deionized distilled water until neutral, centrifuged, and then dried at $60{ }^{\circ} \mathrm{C}$ overnight.

For sulfur isotope analysis, we generally estimate the sulfur content of the sample (with petrographic observations) to calculate the suitable quantity of initial powder needed to obtain $\sim 4 \mathrm{mg}$ of $\mathrm{Ag}_{2} \mathrm{~S}$. However, for samples with low organic carbon content, at least $1 \mathrm{~g}$ of initial powder is necessary to analyze organic carbon compositions. This can be an issue for samples with high sulfur content, for which the chemical extraction with $\sim 1 \mathrm{~g}$ of powder releases large amounts of $\mathrm{H}_{2} \mathrm{~S}$. In this case, the standard $10 \mathrm{~mL}$ of $\mathrm{AgNO}_{3}$ quickly reaches the saturation and to prevent any $\mathrm{H}_{2} \mathrm{~S}$ loss, the volume of $\mathrm{AgNO}_{3}$ has to be multiplied by 5. It produces large quantities of $\mathrm{Ag}_{2} \mathrm{~S}$ potentially heterogeneous that must be carefully homogenized before sulfur isotope analysis.

\subsection{TOC and organic carbon isotope analysis}

TOC content and $\delta^{13} \mathrm{C}_{\text {org }}$ values were measured for carbonate-free residues obtained by both the standard and the new decarbonation method with a Flash EA1112 elemental analyzer coupled to a Thermo Finnigan DELTA plus XP isotope ratio mass spectrometer interfaced with a ConFlo IV interface at the stable isotope laboratory of the Institut de Physique du Globe de Paris (IPGP, Paris, France). Our results were normalized using three internal standards and an internal standard with 5 different amounts was used to estimate the concentration of $\mathrm{C}(\mathrm{wt} \%)$. Reproducibility of replicated standards is $\pm 0.1 \%$ for $\delta^{13} \mathrm{C}(1 \sigma)$. The $\delta^{13} \mathrm{C}$ value of internal standards was determined using a classic sealed tube combustion 
method (i.e. Dumas combustion) and isotope measurement on a Delta+XP mass spectrometer in Dual Inlet mode (see Ader et al., 1998 for a detailed description of the method). They are calibrated against the NBS-21 international standard and reported with the conventional $\delta$ notation relative to the V-PDB (Vienna Pee Dee Belemnite) standard. Reproducibility of the $\delta^{13} \mathrm{C}_{\text {org }}$ and TOC measurements based on at least triplicate measurements of the samples is usually better than $\pm 0.4 \%$ and $\pm 0.01 \mathrm{wt} \%$, respectively ( $1 \sigma$; Tables 1 and 2 ).

\section{RESULTS \& DISCUSSION}

TOC content and organic carbon isotope compositions for the 21 decarbonated samples from BBDP (South Africa), TCDP3 and PDP1 (Western Australia) drill cores are reported in Tables 1 and 2. All the decarbonated samples present low TOC content between $0.008 \pm 0.001$ and $0.87 \pm 0.04 \mathrm{wt} \%$ and cover a large range of $\delta^{13} \mathrm{C}_{\text {org }}$ between $-57.3 \pm 0.1$ and $-15.8 \pm 0.5 \%$. Values measured by the two methods are in a range characteristic for organic material in Archean rocks $\left(\delta^{13} C_{\text {org }}=-26 \pm 7 \%\right.$ in average; e.g. Schidlowski, 2001 and reference therein). Average reproducibility $(1 \sigma)$, estimated from replicate measurements of TOC and $\delta^{13} \mathrm{C}_{\text {org }}$ after the acidic chromium decarbonation, is similar to that obtained after the standard method with $\pm 0.014 \mathrm{wt} \%$ and $\pm 0.41 \%$ against $0.010 \mathrm{wt} \%$ and $0.33 \%$ respectively, suggesting that no carbon addition (from reactant) or incomplete decarbonation occurred. In order to demonstrate that no carbon isotope fractionation is caused by the acidic chromium chemical protocol for decarbonation, we compared the results obtained after standard and acidic chromium decarbonation on the same powder and on different powders from the same samples (Figure 2).

First, starting from the same initial aliquot, we obtained similar results for both TOC and $\delta^{13} \mathrm{C}_{\text {org }}$ values $\left(\delta^{13} \mathrm{C}_{\mathrm{Cr}}\right.$ versus $\delta^{13} \mathrm{C}_{\text {Std }}$ slope of 0.994 with $\mathrm{R}^{2}=0.995$; Figure 2), suggesting that the new chemical protocol for decarbonation does not induce significant carbon isotope 
fractionation (Figures 2 and 3). Carbon-richest samples (TOC $\geq 0.3 \mathrm{wt} \%$ ) show no significant difference in $\delta^{13} \mathrm{C}_{\text {org }}$ with $\delta^{13} \mathrm{C}_{\mathrm{Cr}}-\delta^{13} \mathrm{C}_{\text {Std }} \leq \pm 0.08 \%$, whereas carbon-poor samples (TOC $\leq 0.1 \mathrm{wt} \%$ ) sometimes display differences reaching $+1.2 \%$. No correlation between the carbonate content and the difference of carbon isotopic values has been observed (Figure 3), further confirming that decarbonation was complete. However, Ader et al. (2009) already observed similar deviations in $\delta^{13} \mathrm{C}_{\text {org }}$ after successive standard decarbonation of samples with low TOC content $<1 \%$ (i.e. $\delta^{13} \mathrm{C}_{\mathrm{org}}$ increased by $0.74 \pm 0.5 \%$ ). Even though these variations are very small compared to the range of $\delta^{13} \mathrm{C}_{\mathrm{org}}$ observed, they are still significant compared to the external reproducibility and should be taken into account in future studies regardless of the method used. We also duplicated one sample of mudstone from the Tumbiana Formation previously analyzed by Thomazo et al. (2009). The good reproducibility of $\pm 0.06 \%$ for $\delta^{13} \mathrm{C}_{\text {org }}$ and $\pm 0.02 \%$ for TOC values estimated between the two studies ( $1 \sigma$; Figure 2 ) allows us to validate the new protocol implemented.

Secondly, we observed less consistency between $\delta^{13} \mathrm{C}_{\text {org }}$ and TOC measurements obtained on different powders from the same sample, with differences between $\delta^{13} \mathrm{C}_{\mathrm{Cr}}$ and $\delta^{13} \mathrm{C}_{\text {Std }}$ varying from -7 to $+4 \%$ and differences in TOC from -0.01 to $+0.2 \mathrm{wt} \%$ (grey dots in Figure 2). These sometimes strong but non-systematic offsets are particularly striking when compared to the results obtained when the two procedures are undertaken on the same powder. These results point to rock sample heterogeneity at the centimeter scale and illustrate the importance of working on unique powder aliquots in particular when studying relations between different isotopic tracers. Therefore, our results demonstrate that the chromium reducing chemistry can be used for decarbonation without significant effects on TOC and $\delta^{13} \mathrm{C}_{\text {org }}$ compared to the standard $\mathrm{HCl}$ decarbonation. This new protocol of decarbonation seems to be perfectly adapted for the analysis of organic matter in the ancient rock record that experienced at least low greenschist facies metamorphism. 
For sedimentary rocks having been exposed to lower thermal conditions, it remains to be demonstrated if this protocol can also be safely used because the high temperatures of the acid attack might induce the breakdown of soluble organic molecules from the condensed organic matter, which may artificially decrease the TOC and modify $\delta^{13} \mathrm{C}_{\mathrm{org}}$. Likewise, modern sediments mostly contain immature organic matter and previous studies have already demonstrated that acidification, even at ambient temperature and lower acidity (down to 0.1 $\mathrm{M} \mathrm{HCl}$ ) might have a significant effect on their $\delta^{13} \mathrm{C}_{\text {org }}$ values (from 0.12 to $1.77 \%$; Bunn et al., 1995, Jacob et al., 2005, Jaschinski et al., 2008, Brodie et al., 2011). In addition, it is highly unlikely that this chemistry, which is known to be a powerful reagent that can reduce some organic substrates, should be applicable for immature organic matter (see Hanson, 1974 for review).

\section{CONCLUSIONS}

Our results suggest that the acidic chromium solution can be used to eliminate inorganic carbon without significantly influencing the chemical composition of organic matter in rock samples of lower greenschist metamorphic grade or higher. This method is not only less sample consuming but also less time-consuming and ensures that bulk organic carbon and sulfur isotope measurements are performed on the exact same samples. Nevertheless, given the effects of simple $\mathrm{HCl}$ acidification on the $\delta^{13} \mathrm{C}_{\text {org }}$ values of modern samples (Brodie et al., 2011) as well as Neoproterozoic samples (Ader et al., 2009), we recommend that this new method should be tested before being applied to lower maturity samples.

\section{ACKNOWLEDGMENTS}


We acknowledge the financial support from the UnivEarths Labex program of Sorbonne Paris Cite (ANR 11-IDEX-00005-02). This is Institut de Physique du Globe de Paris contribution 3821.

\section{REFERENCES}

Ader, M., Macouin, M., Trindade, R.I.F., Hadrien, M., Yang, Z., Sun, Z., and Besse, J., 2009, A multilayered water column in the Ediacaran Yangtze platform? Insights from carbonate and organic matter paired $\delta^{13} \mathrm{C}$ : Earth and Planetary Science Letters no. 288(1), p. 213227.

Barley, M.E., Pickard, A.L., and Sylvester, P.J., 1997, Emplacement of a Large Igneous Province as a possible cause of banded iron formation 2.45 billion years ago: Nature no. 385 , p. 55-58.

Bernasconi, S.M., Barbieri, A., and Simona, M., 1997, Carbon and nitrogen isotope variations in sedimenting organic matter in Lake Lugano: Limnology and Oceanography no. 42(8), p. 1755-1765.

Blake, T.S., Buick, R., Brown, S.J.A., and Barley, M.E., 2004, Geochronology of a Late Archaean flood basalt province in the Pilbara Craton, Australia: constraints on basin evolution, volcanic and sedimentary accumulation, and continental drift rates: Precambrian Research no. 133, p. 143-173.

Bolhar, R., and Van Kranendonk, M.J., 2007, A non-marine depositional setting for the northern Fortescue Group, Pilbara Craton, inferred from trace element geochemistry of stromatolitic carbonates: Precambrian Research no. 155, p. 229-250.

Bontognali, T.R., Sessions, A.L., Allwood, A.C., Fischer, W.W., Grotzinger, J.P., Summons, R.E., and Eiler, J.M., 2012, Sulfur isotopes of organic matter preserved in 3.45-billion- 
year-old stromatolites reveal microbial metabolism: Proceedings of the National Academy of Sciences no. 109(38), p. 15146-15151.

Bosley, K.L., and Wainright, S.C., 1999, Effects of preservatives and acidification on the stable isotope ratios $(15 \mathrm{~N}: 14 \mathrm{~N}, 13 \mathrm{C}: 12 \mathrm{C})$ of two species of marine animals: Canadian Journal of Fisheries and Aquatic Sciences no. 56(11), p. 2181-2185.

Brasier M.D., Green, O.R., Jephcoat, A.P., Kleppe, A.K., Van Kranendonk, M.J., Lindsay, J.F., ... and Grassineau, N.V., 2002, Questioning the evidence for Earth's oldest fossils: Nature no. 416, p. 76-81.

Brodie, C.R., Leng, M.J., Casford, J.S., Kendrick, C.P., Lloyd, J.M., Yongqiang, Z., and Bird, M.I., 2011, Evidence for bias in $\mathrm{C}$ and $\mathrm{N}$ concentrations and $\delta^{13} \mathrm{C}$ composition of terrestrial and aquatic organic materials due to pre-analysis acid preparation methods: Chemical Geology no. 282(3), p. 67-83.

Buick R., Dunlop J.S., and Groves D.I., 1981, Stromatolite recognition in ancient rocks: an appraisal of irregularly laminated structures in an Early Archaean chert-barite unit from North Pole, Western Australia. Alcheringa: An Australasian Journal of Palaeontology no. 5, p. 161-181.

Buick, R., 1992, The antiquity of oxygenic photosynthesis: evidence from stromatolites in sulphate-deficient Archaean lakes: Science no. 225, p. 74-77.

Bunn, S.E., Loneragan, N.R., and Kempster, M.A., 1995, Effects of acid washing on stable isotope ratios of $\mathrm{C}$ and $\mathrm{N}$ in penaeid shrimp and seagrass: Implications for food-web studies using multiple stable isotopes: Limnology and Oceanography no. 40(3), p. 622625.

Burton, E.D., Sullivan, L.A., Bush, R.T., Johnston, S.G., and Keene, A.F., 2008, A simple and inexpensive chromium-reducible sulfur method for acid-sulfate soils: Applied Geochemistry no. 23(9), p. 2759-2766. 
Byerly, G.R., Kröner, A., Lowe, D.R., Todt, W., and Walsh, M.M., 1996, Prolonged magmatism and time constraints for sediment deposition in the early Archean Barberton greenstone belt: evidence from the Upper Onverwacht and Fig Tree groups: Precambrian Research no. 78(1), p. 125-138.

Canfield, D., Raiswell, R., Westrich, J., Reaves, C., and Berner, R., 1986, The use of chromium reduction in the analysis of reduced inorganic sulfur in sediments and shales: Chemical Geology no. 54 (1-2), p. 149-155.

Carabel, S., Godínez-Domínguez, E., Verísimo, P., Fernández, L., and Freire, J., 2006, An assessment of sample processing methods for stable isotope analyses of marine food webs: Journal of Experimental Marine Biology and Ecology no. 336(2), p. 254-261.

Chanton, J.P., and Lewis, F.G., 1999, Plankton and dissolved inorganic carbon isotopic composition in a river-dominated estuary: Apalachicola Bay, Florida: Estuaries no. 22(3), p. 575-583.

Craig, H., 1953, The geochemistry of the stable carbon isotopes: Geochimica et Cosmochimica Acta no. 3(2), p. 53-92.

Dunlop, J.S.R., 1978, Shallow-water sedimentation at North Pole, Pilbara Block, Western Australia: University Western Australia, Geology Department \& University Extension, Publication no. 2, p. 30-38.

Fossing, H., and Jørgensen, B.B., 1989, Measurement of bacterial sulfate reduction in sediments: evaluation of a single-step chromium reduction method: Biogeochemistry no. 8(3), p. 205-222.

French, K.L., Hallmann, C., Hope, J.M., Schoon, P.L., Zumberge, J.A., Hoshino, Y., ... and Buick, R., 2015, Reappraisal of hydrocarbon biomarkers in Archean rocks: Proceedings of the National Academy of Sciences no. 112(19), p. 5915-5920. 
Froehlich, P.N., 1980, Analysis of organic carbon in marine sediments: Limnology and Oceanography no.25, p. 564-572.

Garrels, R.M., and Mackenzie, F.T., 1971, Evolution of sedimentary rocks: Norton, NY, pp. 397.

Grey, J., Jones, R.I., and Sleep, D., 2001, Seasonal changes in the importance of the source of organic matter to the diet of zooplankton in Loch Ness, as indicated by stable isotope analysis: Limnology and Oceanography no. 46(3), p. 505-513.

Gröger, J., Franke, J., Hamer, K., and Schulz, H.D., 2009, Quantitative recovery of elemental sulfur and improved selectivity in a chromium-reducible sulfur distillation: Geostandards and Geoanalytical Research no. 33(1), p. 17-27.

Hanson, J.R., 1974, Applications of chromium (II) salts in preparative organic chemistry. Synthesis no. 1974(01), p. 1-8.

Hedges, J.I., and Stern, J.H., 1984, Carbon and nitrogen determinations of carbonatecontaining solids: Limnology and Oceanography no. 29(3), p. 657-663.

Hoashi, M., Bevacqua, D.C., Otake, T., Watanabe, Y., Hickman, A.H., Utsunomiya, S., and Ohmoto, H., 2009, Primary haematite formation in an oxygenated sea 3.46 billion years ago: Nature Geoscience no. 2(4), p. 301-306.

Hofmann A., and Harris C., 2008, Silica alteration zones in the Barberton greenstone belt: a window into subseafloor processes 3.5-3.3 Ga ago: Chemical Geology no. 257, p. 224-242.

Holmquist, R.K., 1969, Stereochemistry of the reduction of tertiary cyclohexyl halides by chromium (II) complexes: Theses, Dissertations, Professional Papers no. 8214.

Kaufman, A.J., Johnston, D.T., Farquhar, J., Masterson, A.L., Lyons, T.W., Bates, S., ... and Buick, R., 2007, Late Archean biospheric oxygenation and atmospheric evolution: Science no. 317(5846), p. 1900-1903. 
Knauth, L.P., and Lowe, D.R., 2003, High Archaean climatic temperature inferred from oxygen isotope geochemistry of cherts in the 3.5 Ga Swaziland Supergroup, South Africa: Geological Society of America Bulletin no. 115, p. 566-580.

Kröner, A., Byerly, G.R., and Lowe, D.R., 1991, Chronology of Early Archaean granitegreenstone evolution in the Barberton Mountain Land, South Africa, based on precise dating by single zircon evaporation: Earth Planetary Science Letter no. 103, p. 41-54.

Garcia-Ruiz J.M., Hyde, S.T., Carnerup, A.M., Christy, A.G., Van Kranendonk, M.J., and Welham, N.J., 2003, Self-assembled silica-carbonate structures and detection of ancient microfossils: Science no. 302, p. 1194-1197.

Grotzinger, J.P., and Rothman, D.H., 1996, An abiotic model for stromatolite morphogenesis: Nature no. 383, p. 423-425.

Farquhar, J., Bao, H., and Thiemens, M., 2000, Atmospheric influence of earth's earliest sulfur cycle: Science no. 289 (5480), p. 756-758.

Farquhar, J., Wu, N., Canfield, D. E., and Oduro, H., 2010, Connections between sulfur cycle evolution, sulfur isotopes, sediments, and base metal sulfide deposits: Economic Geology no. 105(3), p. 509-533.

Jacob, U., Mintenbeck, K., Brey, T., Knust, R., and Beyer, K., 2005, Stable isotope food web studies: a case for standardized sample treatment: Marine Ecology Progress Series no. 287, p. $251-253$.

Jaschinski, S., Hansen, T., and Sommer, U., 2008, Effects of acidification in multiple stable isotope analyses: Limnology and Oceanography: Methods no. 6, p. 12-15.

Johnston, D.T., Farquhar, J., and Canfield, D.E., 2007, Sulfur isotope insights into microbial sulfate reduction: when microbes meet models: Geochimica et Cosmochimica Acta no. 71(16), p. 3929-3947. 
Labidi, J., Cartigny, P., Birck, J.L., Assayag, N., and Bourand, J.J., 2012, Determination of sulfur isotopes in glasses: A reappraisal of the MORB $\delta^{34} \mathrm{~S}$ : Chemical Geology no. 334, p. 189-198.

Lepot, K., Benzerara, K., Brown, G.E., and Philippot, P., 2008, Microbially influenced formation of 2,724-million-year-old stromatolites: Nature Geoscience no. 1, p. 118-121.

Lorrain, A., Savoye, N., Chauvaud, L., Paulet, Y.M., and Naulet, N., 2003, Decarbonation and preservation method for the analysis of organic $\mathrm{C}$ and $\mathrm{N}$ contents and stable isotope ratios of low-carbonated suspended particulate material: Analytica Chimica Acta no. 491(2), p. 125-133.

Lowe D.R., 1994, Abiological origin of described stromatolites older than 3.2 Ga: Geology no. 22 , p. 387-390.

Lowe, D.R., and Tice, M.M., 2007, Tectonic controls on atmospheric, climatic, and biological evolution 3.5-2.4 Ga: Precambrian Research no. 158(3), p. 177-197.

Martin, D.McB., Li, Z.X., Nemchin, A.A., and Powell, CMcA, 1998, A pre-2.2Ga age for giant hematite ores of the Hamersley Province, Australia: Economical Geology no. 93, p. 1084-1090.

Martindale, R.C., Strauss, J.V., Sperling, E.A., Johnson, J.E., Van Kranendonk, M.J., Flannery, D., ... and Schrag, D.P., 2015, Sedimentology, chemostratigraphy, and stromatolites of lower Paleoproterozoic carbonates, Turee Creek Group, Western Australia: Precambrian Research no. 266, p. 194-211.

Mojzsis S.J., Arrhenius, G., McKeegan, K.D., Harrison, T.M., Nutman, A.P., and Friend, C.R.L., 1996, Evidence for life on Earth before 3,800 million years ago: Nature no. 384, p. $55-59$. 
Oduro, H., Kamyshny, A., Guo, W., and Farquhar, J., 2011, Multiple sulfur isotope analysis of volatile organic sulfur compounds and their sulfonium precursors in coastal marine environments: Marine Chemistry no. 124(1), p. 78-89.

Philippot, P., Van Zuilen, M., Lepot, K., Thomazo, C., Farquhar, J., \& Van Kranendonk, M.J., 2007, Early Archean microorganisms preferred elemental sulfur, not sulfate: Science no. 317 , p. $1534-1535$.

Philippot, P., Van Kranendonk, M., Van Zuilen, M., Lepot, K., Rividi, N., Teitler, Y., ... and de Wit, M., 2009, Early traces of life investigations in drilling Archean hydrothermal and sedimentary rocks of the Pilbara Craton, Western Australia and Barberton Greenstone Belt, South Africa: Comptes Rendus Palevol no. 8(7), p. 649-663.

Philippot, P., van Zuilen, M., and Rollion-Bard, C., 2012, Variations in atmospheric sulphur chemistry on early Earth linked to volcanic activity: Nature Geoscience no. 5(9), p. 668674.

Rice, C.A., Tuttle, M.L., and Reynolds, R.L., 1993, The analysis of forms of sulfur in ancient sediments and sedimentary rocks: comments and cautions: Chemical Geology no. 107(12), p. 83-95.

Schidlowski, M., 2001, Carbon isotopes as biogeochemical recorders of life over $3.8 \mathrm{Ga}$ of Earth history: evolution of a concept: Precambrian Research no. 106(1), p. 117-134.

Schopf J.W., Kudryavtsev A.B., Agresti D.G., Wdowiak T.J., and Czaja A.D., 2002, LaserRaman imagery of Earth's earliest fossils: Nature no. 416, p. 73-76.

Schopf, J.W., Kudryavtsev, A.B., Czaja, A.D., and Tripathi, A.B., 2007, Evidence of Archean life: stromatolites and microfossils: Precambrian Research no. 158(3), p. 141-155.

Schubert, C.J., and Nielsen, B., 2000, Effects of decarbonation treatments on $\delta^{13} \mathrm{C}$ values in marine sediments: Marine Chemistry no. 72(1), p. 55-59. 
Sullivan, L.A., Bush, R.T., and McConchie, D.M., 2000, A modified chromium-reducible sulfur method for reduced inorganic sulfur: optimum reaction time for acid sulfate soil. Soil Research no. 38(3), p.729-734.

Thomazo, C., Ader, M., Farquhar, J., and Philippot, P., 2009, Methanotrophs regulated atmospheric sulfur isotope anomalies during the Mesoarchean (Tumbiana Formation, Western Australia): Earth and Planetary Science Letters no. 279(1), p. 65-75.

Thomazo, C., Pinti, D.L., Busigny, V., Ader, M., Hashizume, K., and Philippot, P., 2009b, Biological activity and the Earth's surface evolution: insights from carbon, sulfur, nitrogen and iron stable isotopes in the rock record: Comptes Rendus Palevol no. 8(7), p. 665-678.

Thorne, A.M., and Trendall, A.F., 2001, Geology of the Fortescue Group, Pilbara Craton, Western Australia: Geological Survey of Western Australia Bulletin no. 144, p. 249.

Tice M.M., Bostick B.C., and Lowe D.R., 2004, Thermal history of the 3.5-3.2 Ga Onverwacht and Fig Tree Groups, Barberton greenstone belt, South Africa, inferred by Raman microspectroscopy of carbonaceous material: Geology no. 32, p. 37-40.

Traube, W., and Passarge, W., 1916, Über das Verhalten der Chromoxydul-Salze zu Acetylen und über die reduzierenden Wirkungen der Salze des zweiwertigen Chroms: European Journal of Inorganic Chemistry no. 49(2), p. 1692-1700.

Tuttle, M.L., Goldhaber, M.B., and Williamson, D.L., 1986, An analytical scheme for determining forms of sulphur in oil shales and associated rocks: Talanta no. 33(12), p. 953961.

Van Kranendonk, M.J., and Mazumder, R., 2015, Two Paleoproterozoic glacio-eustatic cycles in the Turee Creek Group, Western Australia: Geological Society of America Bulletin no. 127, p. 596-607.

Van Kranendonk, M.J., Mazumder, R., Yamaguchi, K.E., Yamada, K., Ikehara, M., 2015, Sedimentology of the Paleoproterozoic Kungarra Formation, Turee Creek Group, Western 
Australia: a conformable record of the transition from early to modern Earth: Precambrian Research no. 256, p. 314-343.

van Zuilen M.A., Lepland A., and Arrhenius G., 2002, Reassessing the evidence for the earliest traces of life: Nature no. 418, p. 627-630.

Viljoen, M.J., and Viljoen, R.P., 1969, An introduction to the geology of the Barberton granite-greenstone terrain: Geological Society of South Africa Special Publication no. 2, p. 9-28.

Wacey, D., Saunders, M., Brasier, M.D., and Kilburn, M.R., 2011, Earliest microbially mediated pyrite oxidation in $~ 3.4$ billion-year-old sediments: Earth and Planetary Science Letters no. 301(1), p. 393-402.

Weliky, K., Suess, E., Ungerer, C.A., Muller, P.J., and Fischer, K., 1983, Problems with accurate carbon measurements in marine sediments and particulate matter in seawater: a new approach: Limnology and Oceanography no. 28(6), p. 1252-1259.

Wu, J., Calvert, S.E., Wong, C.S., and Whitney, F.A., 1999, Carbon and nitrogen isotopic composition of sedimenting particulate material at Station Papa in the subarctic northeast Pacific: Deep Sea Research Part II: Topical Studies in Oceanography no. 46(11), p. $2793-$ 2832.

Yamaguchi, K.E., Kiyokawa, S., Ito, T., Ikehara, M., Kitajima, F., and Suganuma, Y., 2009, Clues of Early Life: Dixon Island-Cleaverville Drilling Project (DXCL-DP) in the Pilbara Craton of Western Australia: Scientific Drilling no. 7, p. 34-37.

Zhabina, N.N., and Volkov, I.I., 1978, A method of determination of various sulfur compounds in sea sediments and rocks: In Environmental biogeochemistry and geomicrobiology vol. 3: Methods, metals and assessment, p. 735-746. 


\section{FIGURE CAPTIONS}

Figure 1: Experimental set-up for sulfide sulfur extraction and sample powder decarbonation. The acid attack consist in $20 \mathrm{~mL}$ of $\mathrm{CrCl}_{2}$ solution and $10 \mathrm{~mL}$ of $\mathrm{HCl}(6 \mathrm{~N})$. The solution with ground sample is kept at sub-boiling temperature $\left(\sim 100{ }^{\circ} \mathrm{C}\right)$ and a continuous flow of $\mathrm{N}_{2}$ is bubbling through it. At the end of the reaction, we recovered the extracted sulfide sulfur as $\mathrm{Ag}_{2} \mathrm{~S}$ (in red) for sulfur isotope analyses and the residual decarbonated sample powder (in blue) for organic carbon analyses.

Figure 2: Comparison of $\delta^{13} \mathrm{C}_{\mathrm{org}}$ values (A) and TOC content (B) obtained after standard $\mathrm{HCl}$ decarbonation (Std) and reaction with acidic chromium solution for sulfur extraction $(\mathrm{Cr})$. The black dots correspond to the analyses performed on the same initial aliquot whereas the grey dots correspond to the results obtained on different initial sample powders. The linear regression is associated with the black dots. Note the good agreement between the two techniques with $\mathrm{R}^{2}>0.98$ for both $\delta^{13} \mathrm{C}_{\text {org }}$ values and TOC contents.

Figure 3: Variations of $\delta^{13} \mathrm{C}$ values (A) and TOC content (B) obtained by the two methods as a function of carbonate content of the samples. The analyses performed on the exact same aliquot (black dots) show small deviations for both TOC and $\delta^{13} \mathrm{C}_{\text {org }}$ values suggesting that the new chemical protocol for decarbonation does not induce significant carbon isotope fractionation. $\delta^{13} \mathrm{C}_{\mathrm{org}}$ and TOC measurements are less consistent when obtained on different powders from the same sample (grey dots, $\delta^{13} \mathrm{C}_{\mathrm{Cr}-\mathrm{Std}}> \pm 1 \%$ and $\mathrm{TOC}_{\mathrm{Cr}-\mathrm{Std}}$ up to $0.2 \mathrm{wt} \%$ ). 
Table 1: $\delta^{13} \mathrm{C}_{\text {org }}$ and TOC measured after standard and new decarbonation of same initial sample powders. Carbonate content and $\delta^{13} \mathrm{C}_{\text {carb }}$ have also been determined on the same samples. Underlined italic values are from Thomazo et al. (2009).

\begin{tabular}{|c|c|c|c|c|c|c|c|c|c|c|c|c|c|c|}
\hline \multirow[b]{2}{*}{ Formation } & \multirow[b]{2}{*}{ Lithology } & \multirow[b]{2}{*}{ Sample } & \multicolumn{4}{|c|}{ Decarbonation by chromium solution } & \multicolumn{4}{|c|}{ Standard decarbonation } & \multicolumn{4}{|c|}{ Carbonate content } \\
\hline & & & $\begin{array}{c}\delta^{13} \mathrm{C}_{\mathrm{Cr}} \\
(\% 0) \\
\end{array}$ & $1 \sigma$ & $\begin{array}{l}\mathrm{TOC}_{\mathrm{Cr}} \\
(\mathrm{wt} \%)\end{array}$ & $1 \sigma$ & $\begin{array}{c}\delta^{13} \mathrm{C}_{\mathrm{Std}} \\
(\% \mathrm{\%})\end{array}$ & $1 \sigma$ & $\begin{array}{l}\mathrm{TOC}_{\text {Std }} \\
(\mathrm{wt} \%)\end{array}$ & & $\begin{array}{c}\delta^{13} \mathrm{C}_{\mathrm{Carb}} \\
(\% \mathrm{\%})\end{array}$ & $1 \sigma$ & $\%$ Carb & $1 \sigma$ \\
\hline Mapepe & $\begin{array}{l}\text { Ferruginous } \\
\text { chert }\end{array}$ & BBDP_52.72 & -19.10 & 1.42 & 0.020 & 0.005 & -19.31 & 0.78 & 0.019 & 0.001 & 0.65 & 0.02 & 33.10 & 1.65 \\
\hline Mapepe & Bedded barite & BBDP_67.95 & -26.09 & 0.39 & 0.009 & 0.002 & -26.88 & 0.7 & 0.008 & 0.001 & -1.51 & 0.00 & 0.250 & 0.003 \\
\hline Mapepe & $\begin{array}{l}\text { Felsic } \\
\text { volcanics }\end{array}$ & BBDP_68.05 & -23.66 & 0.22 & 0.015 & 0.001 & -23.63 & 0.53 & 0.015 & 0.002 & 0.42 & 0.13 & 35.46 & 1.26 \\
\hline Mapepe & $\begin{array}{l}\text { Felsic } \\
\text { volcanics }\end{array}$ & BBDP_68.42 & -26.75 & 0.37 & 0.023 & 0.001 & 50 & 0.15 & 0.025 & 0.003 & 1.10 & 0.06 & 32.61 & 0.26 \\
\hline Mapepe & Bedded barite & BBDP_78.18 & -27.56 & 0.05 & 0.031 & 0.002 & -26.59 & 0.10 & 0.042 & 0.004 & -6.01 & 0.16 & 0.070 & 0.001 \\
\hline Mendon & $\begin{array}{l}\text { Laminated } \\
\text { black chert }\end{array}$ & BBDP_95.41 & -30.14 & 0.08 & 0.356 & 0.005 & -30.22 & 0.08 & 0.398 & 0.002 & -3.82 & 0.01 & 0.50 & 0.02 \\
\hline Mendon & $\begin{array}{l}\text { Laminated } \\
\text { black chert }\end{array}$ & BBDP_114.38 & -31.26 & & & 0.02 & -31.22 & 0.15 & 0.87 & 0.04 & -7.03 & 0.04 & 8.13 & 0.02 \\
\hline Mendon & $\begin{array}{l}\text { Laminated } \\
\text { black chert }\end{array}$ & BBDP_139.8 & & 0.20 & 0.30 & 0.01 & -28.43 & 0.10 & 0.249 & 0.005 & -4.28 & 0.18 & 14.40 & 0.55 \\
\hline Turee Creek & $\begin{array}{l}\text { Laminated } \\
\text { mudstone }\end{array}$ & TCDP3_100.52 & -27.49 & 0.70 & 0.095 & 0.029 & -27.09 & 0.11 & 0.106 & 0.004 & 0.36 & 0.40 & 27.33 & 0.03 \\
\hline Turee Creek & $\begin{array}{l}\text { Laminated } \\
\text { mudstone }\end{array}$ & TCDP3_135.16 & -27.87 & 0.67 & 0.16 & 0.06 & -27.06 & 0.08 & 0.111 & 0.004 & -0.10 & 0.40 & 19.68 & 0.03 \\
\hline Turee Creek & Mudstone & TCDP3_156.54 & -29.04 & 0.51 & 0.136 & 0.036 & -28.85 & 0.14 & 0.112 & 0.007 & -5.55 & 0.40 & 9.56 & 0.03 \\
\hline Turee Creek & Mudstone & TCDP3_164.36 & -29.83 & 0.48 & 0.130 & 0.062 & -29.72 & 0.26 & 0.100 & 0.005 & & & & \\
\hline Turee Creek & Quartzite & TCDP3_183.7 & -28.89 & 0.71 & 0.042 & 0.015 & -27.68 & 0.25 & 0.012 & 0.001 & -6.08 & 0.40 & 4.19 & 0.03 \\
\hline Tumbiana & $\begin{array}{l}\text { Homogeneous } \\
\text { mudstone }\end{array}$ & PDP1_44.5 & -55.82 & 0.24 & 0.433 & 0.006 & $\underline{-55.9}$ & $\underline{0.4}$ & $\underline{0.40}$ & $\underline{0.03}$ & $\underline{-7.7}$ & $\underline{0.4}$ & $\underline{25.80}$ & $\underline{0.03}$ \\
\hline
\end{tabular}


Table 2: $\delta^{13} \mathrm{C}_{\text {org }}$ and TOC measured after standard and new decarbonation of different initial sample aliquots. Carbonate content and $\delta^{13} \mathrm{C}_{\text {carb }}$ have also been determined on the same samples.

\begin{tabular}{|c|c|c|c|c|c|c|c|c|c|c|c|c|c|c|}
\hline \multirow{2}{*}{ Formation } & \multirow{2}{*}{ Lithology } & \multirow{2}{*}{ Sample } & \multicolumn{4}{|c|}{ Decarbonation by chromium solution } & \multicolumn{4}{|c|}{ Standard decarbonation } & \multicolumn{4}{|c|}{ Carbonate content } \\
\hline & & & $\begin{array}{c}\delta^{13} \mathrm{C}_{\mathrm{Cr}} \\
(\% \mathrm{o}) \\
\end{array}$ & $1 \sigma$ & $\begin{array}{l}\mathrm{TOC}_{\mathrm{Cr}} \\
(\mathrm{wt} \%)\end{array}$ & $1 \sigma$ & $\begin{array}{c}\delta^{13} \mathrm{C}_{\mathrm{Std}} \\
(\% \mathrm{o})\end{array}$ & $1 \sigma$ & $\begin{array}{l}\mathrm{TOC}_{\text {Std }} \\
(\mathrm{wt} \%)\end{array}$ & $1 \sigma$ & $\begin{array}{c}\delta^{13} \mathrm{C}_{\mathrm{Carb}} \\
(\% \mathrm{o})\end{array}$ & $1 \sigma$ & $\%$ Carb & $1 \sigma$ \\
\hline Tumbiana & $\begin{array}{l}\text { Laminated } \\
\text { mudstone }\end{array}$ & PDP1_88.2 & -57.26 & 0.08 & 0.410 & 0.001 & -52.70 & 0.40 & 0.21 & 0.03 & -1.10 & 0.40 & 51.20 & 0.03 \\
\hline Tumbiana & Siltstone & PDP1_68.9C & -51.55 & 0.10 & 0.290 & 0.002 & -44.90 & 0.40 & 0.09 & 0.03 & 0.40 & 0.40 & 63.80 & 0.03 \\
\hline Tumbiana & $\begin{array}{l}\text { Homogeneous } \\
\text { mudstone }\end{array}$ & PDP1_69.5 & -49.84 & 0.27 & 0.135 & 0.002 & -44.50 & 0.40 & 0.11 & 0.03 & 0.60 & 0.40 & 40.40 & 0.03 \\
\hline Mapepe & $\begin{array}{l}\text { Ferruginous } \\
\text { chert }\end{array}$ & BBDP_39.75 & -15.78 & 0.43 & 0.034 & 0.001 & -18.46 & 0.16 & 0.026 & 0.001 & -0.59 & 0.01 & 9.94 & 0.05 \\
\hline Mapepe & $\begin{array}{l}\text { Felsic } \\
\text { volcanics }\end{array}$ & BBDP_45.99 & -27.65 & 0.96 & 0.019 & 0.004 & -31.53 & 0.31 & 0.015 & 0.000 & -0.18 & 0.04 & 0.46 & 0.01 \\
\hline Mapepe & $\begin{array}{l}\text { Felsic } \\
\text { volcanics }\end{array}$ & BBDP_56.66 & -25.94 & & 0.028 & 0.004 & -30.22 & 0.41 & 0.038 & 0.002 & 0.67 & 0.18 & 19.84 & 0.43 \\
\hline Mendon & $\begin{array}{l}\text { Altered } \\
\text { komatiite }\end{array}$ & BBDP_160.12 & -28.50 & 0.31 & 0.077 & 0.024 & -25.79 & 1.05 & 0.02 & 0.01 & -1.06 & 0.06 & 15.64 & 0.54 \\
\hline
\end{tabular}




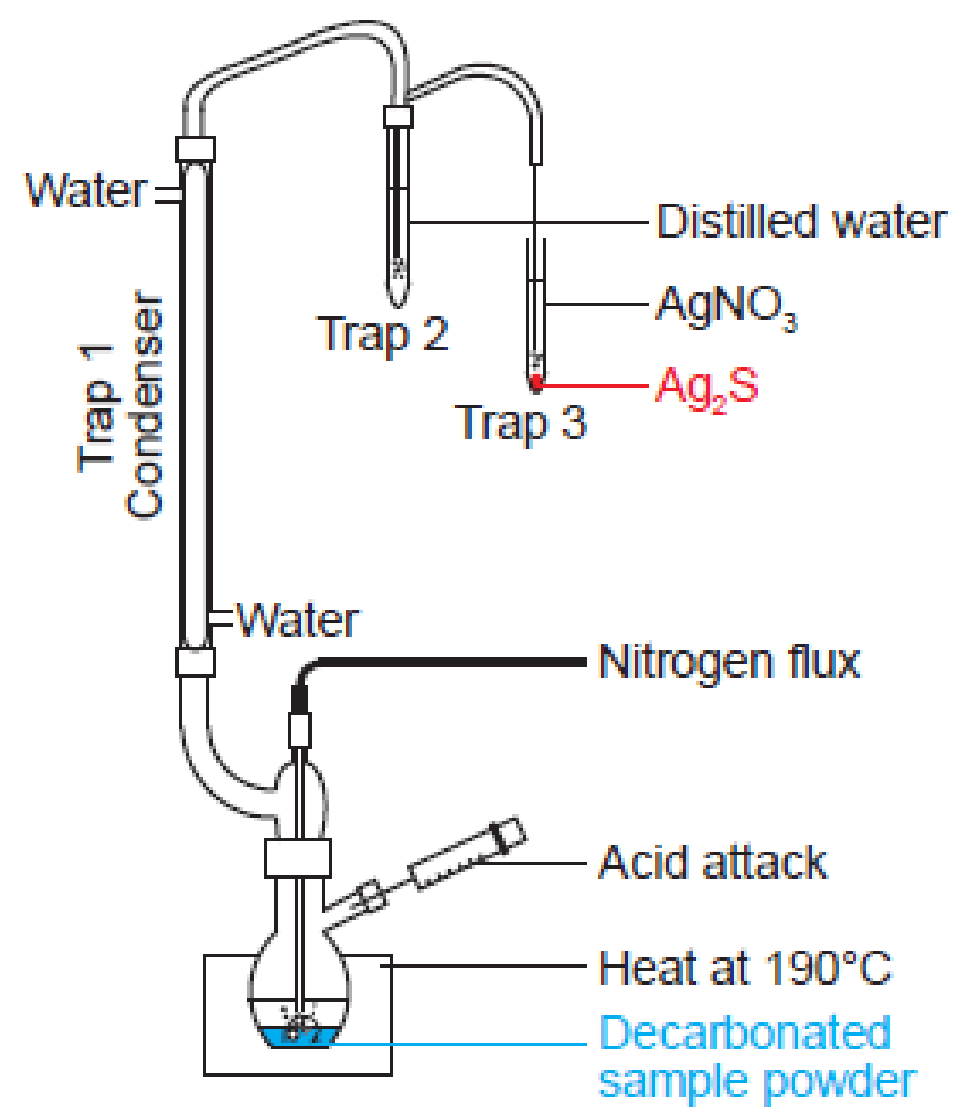

Fig. 1 


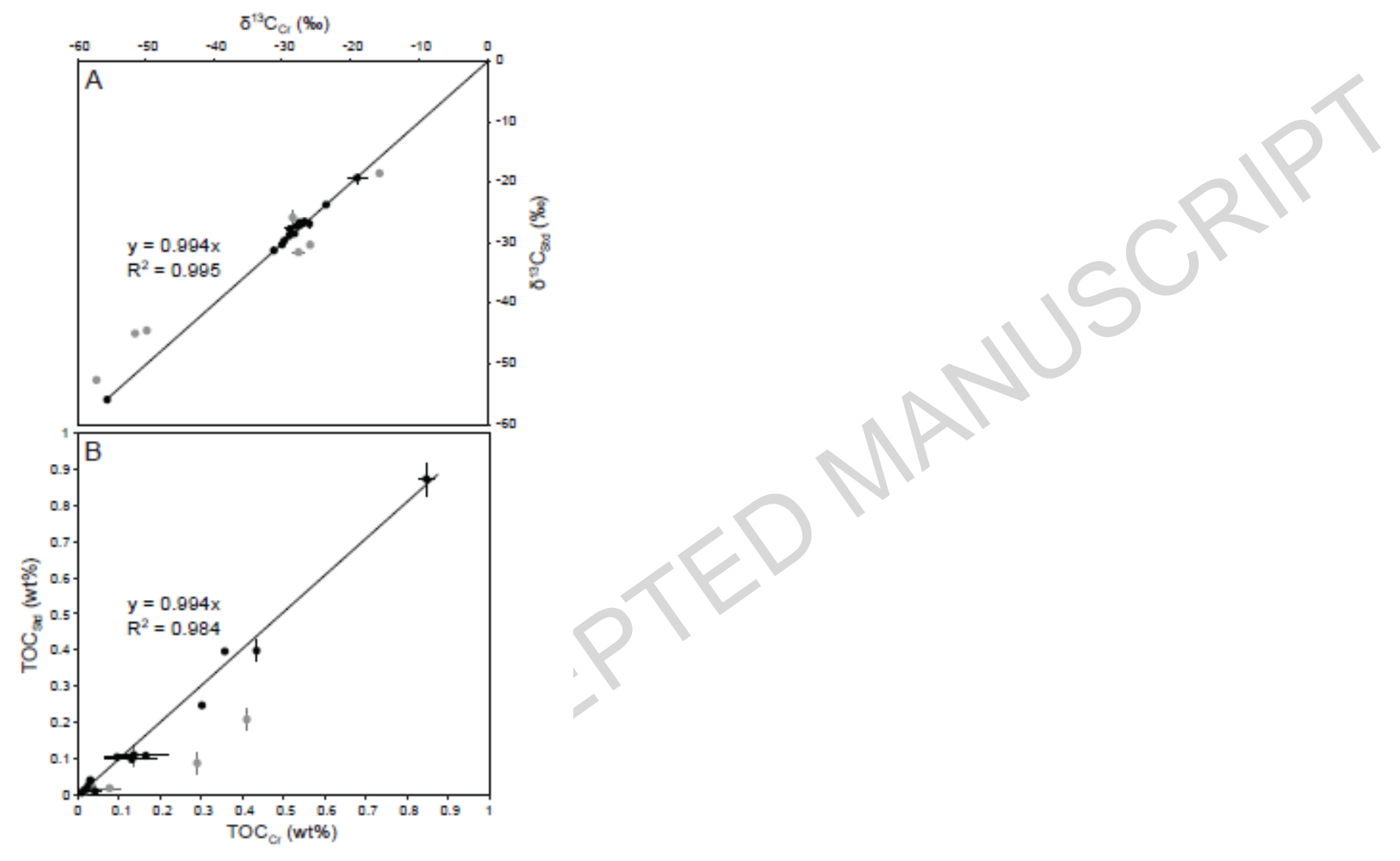

Fig. 2 

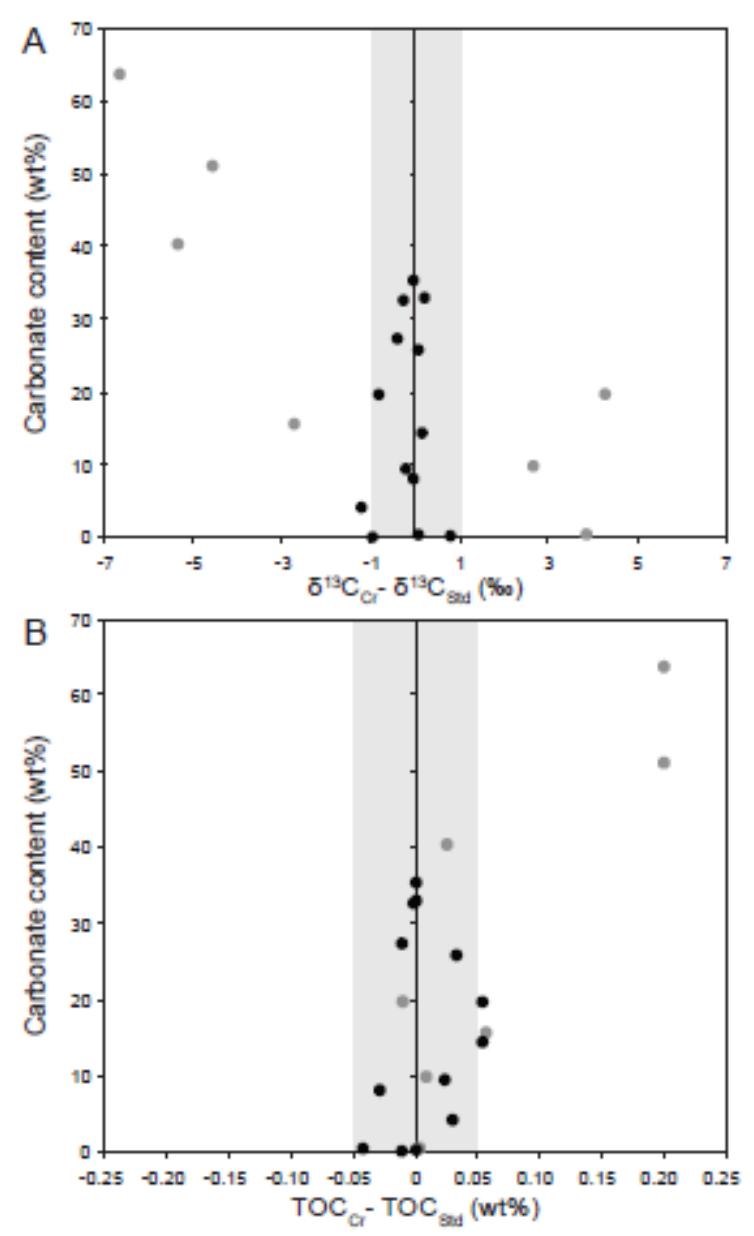

Fig. 3 